\title{
Mast cell-activated bone marrow mesenchymal stromal cells regulate proliferation and lineage commitment of CD34+ progenitor cells
}

\section{Zoulfia Allakhverdi ${ }^{1}{ }^{*}$, Michael R. Comeau ${ }^{2}$, Myriam Armant $^{3}$, Rachana Agrawal ${ }^{4}$, Judith A. Woodfolk ${ }^{4}$, Roma Sehmi ${ }^{5}$, Karen J. Howie ${ }^{6}$, Gail M. Gauvreau ${ }^{6}$ and Guy Delespesse ${ }^{1 *}$}

1 Laboratory on Allergy, CRCHUM Notre-Dame Hospital, Montreal, OC, Canada

2 Inflammation Research, Amgen Inc., Seattle, WA, USA

${ }^{3}$ Center for Human Cell Therapy, Immune Disease Institute, Boston, MA, USA

${ }^{4}$ Department of Medicine, Allergy Division, University of Virginia, Charlottesville, VA, USA

${ }^{5}$ Firestone Institute for Respiratory Health, McMaster University, Hamilton, ON, Canada

${ }^{6}$ Asthma Research Group, McMaster University, Hamilton, ON, Canada

\section{Edited by:}

Anna Rubartelli, IRCCS AOU San Martino IST, Italy

\section{Reviewed by:}

Kottarappat Dileepan, University of Kansas Medical Center, USA

Vito Pistoia, Giannina Gaslini Institute, Italy

*Correspondence:

Zoulfia Allakhverdi and Guy

Delespesse, Laboratory on Allergy,

CRCHUM Notre-Dame Hospital, 1560

Sherbrooke East Street, Pav Mailloux,

M4211-K, Montreal, OC H2L-4M1,

Canada

e-mail: zoulfia.allakhverdieva@

mail.mcgill.ca;

guy.jt.delespesse@umontreal.ca

${ }^{+}$Present address:

Zoulfia Allakhverdi, Department of Hematology/Oncology, Sainte-Justine University Health Center, Montreal, QC, Canada
Background: Shortly after allergen exposure, the number of bone marrow (BM) and circulating $\mathrm{CD}_{34}{ }^{+}$progenitors increases. We aim to analyze the possible mechanism whereby the allergic reaction stimulates BM to release these effector cells in increased numbers. We hypothesize that mast cells (MCs) may play a predominant role in this process.

Objective: To examine the effect of IgE-activated MCs on BM mesenchymal stromal cells which regulate proliferation and differentiation of $\mathrm{CD} 34^{+}$progenitors.

Methods: Primary MCs were derived from $\mathrm{CD}_{3} 4^{+}$precursors and activated with IgE/antiIgE. BM mesenchymal stromal cells were co-cultured with $\mathrm{CD} 34^{+}$progenitor cells and stimulated with IL-1/TNF or IgE/anti-lgE-activated MCs in Transwell system.

Results: BM mesenchymal stromal cells produce low level of thymic stromal lymphopoietin (TSLP) under steady state conditions, which is markedly increased by stimulation with proinflammatory cytokines IL-1 and TNF or IgE-activated MCs. The latter also triggers bone marrow-derived mesenchymal stromal cells production of G-CSF, and GM-CSF while inhibiting SDF-1. MC-activated mesenchymal stromal cells stimulate $\mathrm{CD} 34^{+}$cells to proliferate and to regulate their expression of early allergy-associated genes.

Conclusion and Clinical Relevance: This in vitro study indicates that IgE-activated MCs trigger BM mesenchymal stromal cells to release TSLP and hematopoietic growth factors and to regulate the proliferation and lineage commitment of $\mathrm{CD} 34^{+}$precursor cells. The data predict that the effective inhibition of MCs should impair mobilization and accumulation of allergic effector cells and thereby reduce the severity of allergic diseases.

Keywords: mast cells, bone marrow mesenchymal stromal cells, TSLP, circulating CD34+ progenitor cells, asthma, allergic inflammation, Th2 response

\section{INTRODUCTION}

Although the initial manifestations of a mucosal allergic reaction are localized, recent studies underline a systemic component of allergic diseases and suggest an important role of the bone marrow (BM) in the control of allergic response. Indeed, shortly after allergen exposure BM releases increased numbers of $\mathrm{CD} 34^{+}$hematopoietic precursors and differentiated proinflammatory myeloid cells $(1-3)$. CD $34^{+}$precursors are rapidly recruited to the site of allergen deposition where they display a dual function as both precursors differentiating into eosinophils, basophils, and mast cells (MCs), and proinflammatory effectors

Abbreviations: BM, bone marrow; BM-MSCs, bone marrow-derived mesenchymal stromal cells; DCs, dendritic cells; MCs, mast cells; SDF-1, stromal derived factor 1; TSLP, thymic stromal lymphopoietin. releasing high levels of Th2 cytokines/chemokines (4). However, the specific mechanisms underlying airway allergen exposure and communication with the BM leading to augmented numbers of progenitor cells and their increased release remain to be elucidated.

Bone marrow-derived mesenchymal stromal cells (BM-MSCs) are multipotent progenitor cells with immunomodulatory properties [reviewed in Ref. (5)]. Recent studies suggest that BMMSCs themselves are critical for forming a niche that maintains hematopoietic stem cells (HSCs) and responsible for the production and deposition of the extracellular matrix, the production and concentration of cytokines, and growth factors (6-8). MCs originate from HSCs, which circulate as $\mathrm{CD}_{3} 4^{+}$precursors until they migrate into tissues where they mature to effector cells. Both $\mathrm{CD} 34^{+}$precursors and MCs actively participate in the induction of allergic inflammation by producing high levels of 
Th2 proinflammatory cytokines in response to inflammatory and epithelial cell-derived cytokines, including thymic stromal lymphopoietin (TSLP) $(4,9)$. Since MCs are sentinels of the innate immune system and respond very rapidly (within minutes) by releasing different mediators, they are the best candidates for the early signals generated during allergic response that may impact hematopoietic progenitor cell differentiation/mobilization. Here we tested in an in vitro model the hypothesis that signals produced by inflamed tissues and local microenvironment at the site of allergic inflammation may have a significant role in determining the communication with the BM stroma and MCs may play important role in this cross-talk.

\section{MATERIALS AND METHODS}

\section{CD34+ AND PRIMARY HUMAN MAST CELL CULTURES}

$\mathrm{CD}_{3} 4^{+}$progenitor cells were positively selected from umbilical cord or adult peripheral blood by double passage through columns (Miltenyi Biotech) leading to cellular preparations containing more than $98 \% \mathrm{CD}^{+} 4^{+}$cells and negative for CD3, CD10, CD14, CD19, CD20, CD40, CD56, CD83, CDw125 (IL-5R), and FceR1. All samples were collected after informed consent, using protocols approved by the ethic committee at our institution. To obtain MCs, CD $34^{+}$progenitor cells were cultured in StemPro serum free culture medium (Invitrogen) supplemented with $5 \mathrm{ng} / \mathrm{ml}$ of IL-3 and $100 \mathrm{ng} / \mathrm{ml}$ of SCF as described elsewhere (10). After 1012 weeks of culture, $>98 \%$ of cells were stained for c-kit (BD), FceRI (e-BioScience), and tryptase (Chemicon). MCs were cultured for $96 \mathrm{~h}$ with $\operatorname{IgE}(1 \mu \mathrm{g} / \mathrm{ml}$; generous gift of Dr. K. Ishizaka), then extensively washed and crosslinked with anti-IgE $(0.5 \mu \mathrm{g} / \mathrm{ml}$; RayBiotech Inc.) overnight; their supernatants were collected or in some experiments MCs were used in the upper compartment of Transwell system.

Antibodies and recombinant cytokines used included: antiCD34-APC, anti-CD34-PE, anti-CD117-PE, anti-CD123-PE, anti-CD3-PE, anti-CD14-PE, anti-CD19-FITC, anti-CD20-PE, anti-CD56-PE (all from BD), anti-FceRI (e-BioScience), anti-IL$5 \mathrm{R}$ (generous gift of Dr. Tavernier), polyclonal anti-TSLP (ProScience Inc.), recombinant TNF- $\alpha$, IL-1 $\beta$ (R\&D; 25 and $10 \mathrm{ng} / \mathrm{ml}$, respectively, or $1 \mathrm{ng} / \mathrm{ml}$ each when indicated); IL-3, IL-5 (PeproTech; each used at $5 \mathrm{ng} / \mathrm{ml}$ ). Neutralizing antibody to TSLP (Amgen) and its isotype control antibody were used at $10 \mu \mathrm{g} / \mathrm{ml}$, as in our previous study (4).

\section{PRIMARY HUMAN BONE MARROW-DERIVED MESENCHYMAL STROMAL CELLS}

Human BM-derived mesenchymal stromal cells were established from BM samples (AllCells, Emeryville, CA, USA) by culture in minimum essential medium- $\alpha$, supplemented with $10 \%$ FBS (Hyclone) and $5 \mathrm{ng} / \mathrm{ml}$ of basic fibroblast growth factor (FGF; PeproTech). The cells were plated in 24-well plates until confluent, they were then washed with PBS three times to remove the serum components and were co-cultured with $\mathrm{CD} 34^{+}$progenitor cells or MCs, as indicated. In the experiment to separate MCs and the stromal cell monolayer, Transwell with a $0.45 \mu \mathrm{m}$ filter in $24-$ well plates were used. The supernatants from the various culture conditions were collected and filtered to remove cellular debris. Flow cytometric analysis confirmed that the BM-MSCs expressed
CD9, CD10, CD13, CD29, CD44, CD73, CD90, CD105, CD106, and CD166, but not CD14, CD34, or CD45 (all from BioLegend).

\section{PROLIFERATION ASSAY}

$\mathrm{CD} 4^{+}$cells were labeled with CFSE and placed in the lower compartment of the Transwell system with or without BM-MSCs; in some experiments, IgE-coated MCs $\left(10^{5}\right.$ cells $\left./ \mathrm{ml}\right)$ were cultured in the upper compartment of the Transwell system in the presence or absence of anti-IgE. MCs were removed after $6 \mathrm{~h}$ of culture. At day 3 of cultures, $\mathrm{CD} 34^{+}$cells were gently removed from the BMMSCs layers (adherent cells) and analyzed for their proliferation by FACS.

\section{ASSESSMENT OF CYTOKINE RELEASE}

Cell-free culture supernatants were analyzed for protein content using commercially available kits, including IL-5, IL-13, G-CSF, GM-CSF, SDF-1, and TSLP (all obtained from R\&D).

\section{QUANTITATIVE REAL-TIME PCR}

RNA was isolated using the RNeasy Mini Kit (QIAGEN). cDNA synthesis was performed using the TaqMan Reverse Transcription kit. The CEBPA gene expression assay ID (from Applied Biosystems, ABI) is Hs00269972_s1. The GATA-2 gene expression assay ID is Hs00231119_m1. Quantitative real-time PCR was performed via TaqMan using ABI gene expression assays on a 7900HT Fast Real-Time PCR System. HPRT was used as a control for cDNA input.

\section{IMMUNOCYTOCHEMISTRY}

Bone marrow-MSCs were cultured on eight-chamber slides until they reached the confluence. The cells were stimulated with or without IL-1/TNF or supernatants of activated MCs $(30 \%$ $\mathrm{v} / \mathrm{v}$ ), then fixed and stained for TSLP (polyclonal Ab, ProSci Inc.), developed with AEC (Dako) and counterstained with hematoxylin.

\section{STATISTICAL ANALYSIS}

Student's paired and unpaired $t$ tests were used when appropriate; ${ }^{\star} p<0.05,{ }^{* *} p<0.01,{ }^{* *} p<0.001$.

\section{RESULTS}

\section{BONE MARROW STROMAL CELLS PRODUCE TSLP}

Since TSLP is a growth factor released by thymic stromal cells that exerts its effect on proliferation of immature lymphocytes, we have focused on the role of TSLP in the cross-talk of BMderived mesenchymal stromal cells and $\mathrm{CD} 34^{+}$progenitor cells which is likely to take place within the BM stroma. Unexpectedly, we observed that TSLP is expressed both at protein and mRNA levels by BM-MSCs at low levels under steady state conditions and is markedly enhanced in the presence of the canonical proinflammatory cytokines IL-1 and TNF, which mimic inflammatory condition (Figure 1A). BM-MSCs-derived TSLP is biologically active and specific, as it induced IL-5 and IL-13 production by freshly isolated $\mathrm{CD}_{3}{ }^{+}$progenitor cells following overnight cultures with BM-MSCs in the presence of suboptimal concentrations of IL-1/TNF [just sufficient to exert permissive effect on TSLP, as previously published (9)] and it was suppressed by 
neutralizing mAb to TSLP (Figure 1B). These observations thus suggest that TSLP may be produced under both inflammatory and steady state conditions and could serve as molecular regulator of hematopoiesis and inflammation perhaps via induction of Th2 cytokines by $\mathrm{CD} 34^{+}$progenitor cells.

In view of MCs as the first cells to be activated upon exposure to allergen, we next examined whether activated MCs would exert similar effects as IL-1/TNF on the BM. Indeed, the soluble factors released by IgE/anti-IgE-activated MCs induce TSLP production by BM-MSCs as detected by ELISA (Figure 2A). Moreover, the levels of TSLP present in these culture supernatants were sufficient when used together with IL-1/TNF to induce IL-13 production from $\mathrm{CD} 34^{+}$cells (Figure 2B). These observations were confirmed by immunocytochemistry showing more intense staining of TSLP


FIGURE 1 | Bone marrow-derived mesenchymal stromal cells produce TSLP upon stimulation with the proinflammatory cytokines IL-1 and TNF (A) The expression of TSLP was determined at the mRNA and protein level on the bone marrow-derived mesenchymal stromal cells (BM-MSCs) stimulated with or without IL-1/TNF (10 and $25 \mathrm{ng} / \mathrm{ml}$, respectively); mean $\pm \mathrm{SEM}$ of five experiments. (B) Freshly isolated neonatal $\mathrm{CD} 34^{+}$cells were co-cultured overnight with BM-MSCs in the presence or absence of suboptimal concentrations of IL-1/TNF (1 $\mathrm{ng} / \mathrm{ml}$ of each) and neutralizing antibody to TSLP, as indicated. Isotype control antibody had no biological activity. Supernatants were assessed for IL-5 and IL-13 levels. Mean \pm SEM of eight experiments.

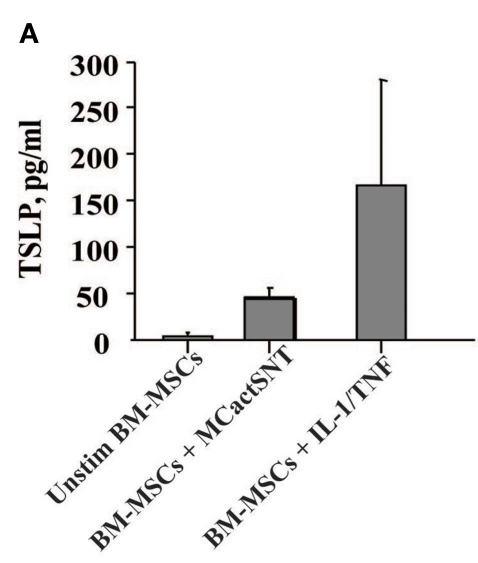

C

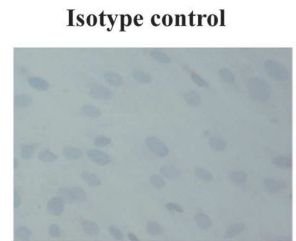

Unstim BM-MSCs



FIGURE 2 | Activated mast cells induce TSLP production by BM-derived mesenchymal stromal cells. (A) Supernatants of activated (IgE/anti-lgE) mast cells (30\% v/v) were added to the BM-MSCs. TSLP expression was analyzed by ELISA. Mean \pm SEM of four experiments. (B) Freshly isolated neonatal $\mathrm{CD}_{3} 4^{+}$cells were cultured overnight with BM-MSCs in the presence or absence of IgE/anti-lgE-activated MCs



BM-MSCs + IL-1/TNF BM-MSCs + MCactSNT




protein on BM-MSCs stimulated with IL-1/TNF or supernatants of activated MCs (Figure 2C). Treatment of BM-MSCs with MCs mediators, including $\mathrm{LTC}_{4}, \mathrm{PGD}_{2}$, tryptase, and histamine alone or in combination did not induce TSLP production, which required the combination of all these mediators in the presence of TNF (Table 1).

\section{ACTIVATED MAST CELLS INDUCE GROWTH FACTOR PRODUCTION BY BONE MARROW MESENCHYMAL STROMAL CELLS}

Since shortly after allergen exposure there is increased proliferation and mobilization of $\mathrm{CD}_{3} 4^{+}$progenitors from the $\mathrm{BM}$ as well as an augmented differentiation of eosinophils, we examined whether activated MCs stimulate BM-MSCs for the increased production of hematopoietic growth factors. In the experiment shown in Figure 3, BM-MSCs were cultured for $6 \mathrm{~h}$ with activated MCs in a Transwell system then MCs were removed and BM-MSCs were kept in culture for another $42 \mathrm{~h}$. In addition to TSLP, BMMSCs released G-CSF and GM-CSF, factors with critical roles in hematopoiesis. Moreover, the production of SDF-1 was significantly reduced in the presence of activated MCs. Attenuation of SDF-1 receptor expression on the $\mathrm{BM} \mathrm{CD} 34^{+}$cells together with

Table 1 | Mast cell mediators' effect on the release of TSLP by BM-MSCs.

\begin{tabular}{ll}
\hline Conditions & TSLP (pg/ml) \\
\hline BM-MSCs (-) & $18 \pm 2.1$ \\
TNF & $35 \pm 5.5$ \\
LTC4 & $\mathrm{N} / \mathrm{D}$ \\
Tryptase & $\mathrm{N} / \mathrm{D}$ \\
Histamine & $\mathrm{N} / \mathrm{D}$ \\
PGD2 & $\mathrm{N} / \mathrm{D}$ \\
LTC4/tryptase/histamine & $\mathrm{N} / \mathrm{D}$ \\
LTC4/tryptase/histamine +TNF & $252 \pm 7.8$ \\
\hline
\end{tabular}

$N / D$, not detected; the results are presented as mean $\pm S E M$. reduction of SDF-1 levels in the $\mathrm{BM}$ was shown to regulate the release of progenitors from $\mathrm{BM}$ in allergen induced asthma (2, 11). Of note, the supernatants of cultures that were harvested at the point when MCs were removed contained no detectable levels of TSLP, G-CSF, and GM-CSF.

\section{BONE MARROW MESENCHYMAL STROMAL CELLS PRIMED WITH ACTIVATED MAST CELLS INDUCE PROLIFERATION OF CD34+ PROGENITORS}

Because allergen exposure increases proliferation of $\mathrm{CD}_{3} 4^{+}$progenitors in the BM (12) and at the site of allergen exposure (13), we next analyzed whether activated MCs would have an effect on the proliferation of the progenitors. Indeed, MCs-derived soluble factors enhanced the proliferation of CFSE-labeled CD $34^{+}$ progenitor cells as determined at day 3 of cultures. Non-activated MCs exerted a small but consistent effect on the proliferation of $\mathrm{CD}^{+}{ }^{+}$cells likely due to background levels of activation. BMMSCs co-cultured with $\mathrm{CD} 34^{+}$cells in the lower compartment of the Transwell system also enhanced progenitor proliferation. The proliferation of $\mathrm{CD} 34^{+}$cells was markedly increased if BMMSCs were preactivated by soluble factors released by IgE/antiIgE-activated MCs in the upper compartment of Transwell, which was removed after $6 \mathrm{~h}$ of culture (Figure 4).

\section{BONE MARROW MESENCHYMAL STROMAL CELLS PRIMED WITH ACTIVATED MAST CELLS REGULATE ALLERGY-RELATED EARLY GENES IN CD34+ PROGENITORS}

To assess whether MC-activated BM-MSCs might prime progenitor cell differentiation into allergic effectors, we have examined the expression of early allergy-related genes in $\mathrm{CD} 34^{+}$progenitor cells. After $10 \mathrm{~h}$ of co-culture with BM-MSCs pre-stimulated with activated $\mathrm{MCs}, \mathrm{CD} 34^{+}$progenitor cells demonstrated downregulated CEBP- $\alpha$ and upregulated GATA-2 expression, two genes known to be implicated in the differentiation of progenitors into allergic effectors (14) (Figure 5). Increased expression of GATA-2 in $\mathrm{CD}_{3}{ }^{+}$progenitors gives rise to eosinophil differentiation, whereas a concomitant decrease in CEBP- $\alpha$ and increase in

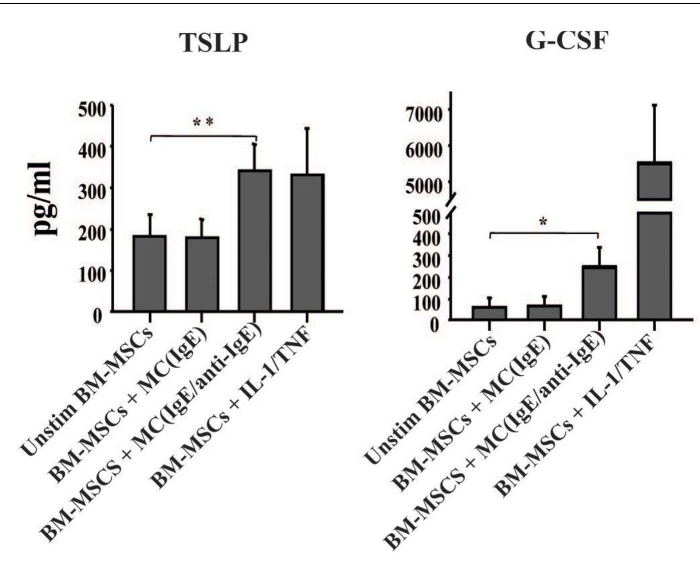

FIGURE 3 | Activated mast cells induce hematopoietic growth factors production by BM-derived mesenchymal stromal cells. BM-MSCs were exposed to non-activated and activated MCs in a Transwell system for $6 \mathrm{~h}$, then Transwell membranes with mast cells were removed; the cultures of


stromal cells were left for additional $42 \mathrm{~h}$ and their supernatants were analyzed for the production of cytokines $(\mathrm{pg} / \mathrm{ml})$. Supernatants of BM-MSCs stimulated with IL-1/TNF (10 and $25 \mathrm{ng} / \mathrm{ml}$, respectively) for $48 \mathrm{~h}$ were used as a positive control. Mean \pm SEM of six to ten experiments. 




GATA-2 enforces basophil/MC differentiation (15). Collectively, these data suggest that mesenchymal stromal cells stimulated with activated MCs regulate proliferation and lineage commitment of $\mathrm{CD} 34^{+}$progenitor cells.

\section{DISCUSSION}

The inflammatory process that occurs following allergen exposure is characterized by the accumulation of immature precursors, eosinophil-committed progenitors, mature eosinophils, MCs, basophils, neutrophils, and $\mathrm{CD} 4^{+} \mathrm{T}$ cells, all of which are of $\mathrm{BM}$ origin. The BM of allergic subjects releases increased amounts of $\mathrm{CD} 34^{+}$progenitor cells that migrate to the sites of allergic inflammation (2); these cells are readily detectable in the bronchial mucosa and the sputum of asthmatic patients, in nasal polyps and in the lesional skin of atopic dermatitis patients $(13,16)$. However, the mechanism behind the increased activation of the BM following airway allergen exposure, resulting in both the release of progenitors into the circulation and the production of new effectors is not known. Here we suggest a possible mechanism by which IgE-activated MCs trigger BM mesenchymal stromal cells to release TSLP and hematopoietic growth factors and to regulate the proliferation and lineage commitment of $\mathrm{CD} 34^{+}$precursor cells.

In recent years, there has been an increasing appreciation of important contribution of BM-related, hematopoietic mechanisms to allergic diseases. Interesting observations indicated that the $\mathrm{BM}$ is able to transfer all allergic manifestations $(17,18)$ while lung transplantation transfers only asthma (19), thus suggesting



FIGURE 5 | Bone marrow-derived mesenchymal stromal cells preactivated with mast cells regulate allergy-related genes in CD34 ${ }^{+}$ progenitors. BM-MSCs were exposed to non-activated or activated mast cells in a Transwell system and freshly isolated CD34+ cells were added to the cultures for $10 \mathrm{~h}$. Early genes for effector differentiation were analyzed in $\mathrm{CD}_{3} 4^{+}$cells following culture with BM-MSCs by real-time PCR. Mean \pm SEM of four experiments.

that resident $\mathrm{BM}$ cells play important role in the regulation of allergic inflammation. Most of the hematopoietic activities in the BM are controlled by the resident mesenchymal stromal cells and their products (20). BM-MSCs have recently been shown to suppress harmful immune responses in patients with steroid-resistant graftversus-host disease (21), severe systemic lupus erythematosus (22), and cardiac disease (23). The authors of many of these studies concluded that BM-MSCs-driven immunosuppression results from a shift in Th1/Th2 balance $(24,25)$. Our results showing that cytokines IL-1 and TNF, which mimic inflammatory conditions, and also the products released by MCs following IgE-mediated cross-linking induce production of Th2-inducing cytokine TSLP by BM-MSCs may shed light on these observations. Functional relevance of this observation is demonstrated by increased IL-5 and IL-13 production by CD34 ${ }^{+}$cells and expression of allergyassociated genes by these progenitor cells after interaction with MC-primed BM-MSCs. Importantly, accumulation of eosinophils and basophils in tissues is characteristic of allergic inflammation in rhinitis, nasal polyposis, and asthma $(26,27)$. These airway tissue inflammatory events may be coincident with relevant changes and fluctuations of circulating and marrow populations of CD34 ${ }^{+}$ progenitors following mediators release by BM-MSCs. Indeed, TSLP was suggested to play direct role in the IL-3-independent differentiation of basophils (28). TSLP may also indirectly be implicated in the observed increased eosinophilopoiesis in the presence of IL-1-treated stromal cells (29) by inducing IL-5 release by $\mathrm{CD} 34^{+}$progenitor cells. Furthermore, increased proliferation and release of $\mathrm{CD}_{3} 4^{+}$cells in the presence of MCs-primed BMMSCs suggest a direct signal between the airway mucosa and $\mathrm{BM}$ that is able to increase $\mathrm{CD} 34^{+}$production and release at times of increased allergic inflammation. Accordingly, hematopoietic growth factors released by BM-MSCs upon stimulation with activated MCs could explain observed increased proliferation of 


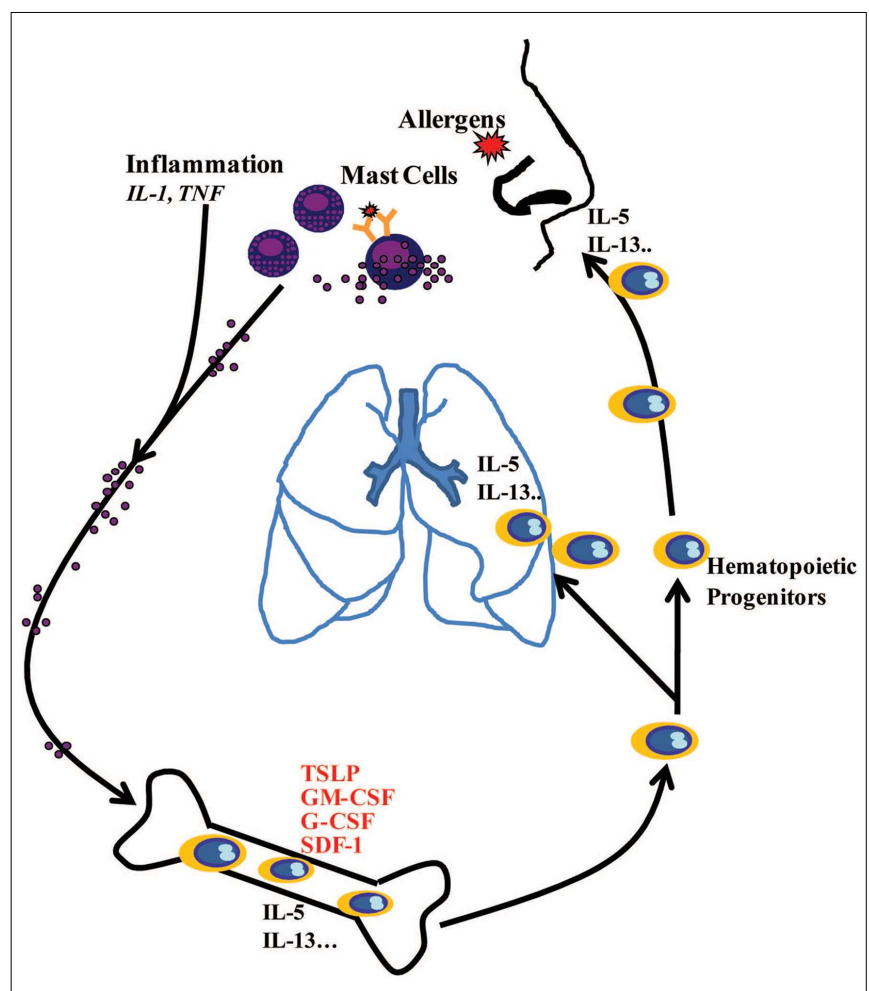

FIGURE 6 | Schematic diagram showing systemic hematopoietic processes involving active communication between mast cells at the site of allergic inflammation and the bone marrow, highlighting how mast cell-released mediators stimulate the bone marrow to produce hematopoietic growth factors, which in turn regulate proliferation and lineage commitment of $\mathrm{CD}^{+} 4^{+}$progenitor cells. $\mathrm{CD} 34^{+}$progenitor cells stimulated with MC-primed BM-MSCs may produce IL-5 and IL-13 in the bone marrow and at the sites of allergic inflammation via TSLP-dependent mechanisms.

$\mathrm{CD}^{+} 4^{+}$cells in asthmatics $24 \mathrm{~h}$ after inhaled allergen challenge (30). In addition to their effects on BM-MSCs, MCs products may also act on epithelial cells inducing their release of TSLP (31) and G-CSF (unpublished observations), which may also affect the activity of BM. The finding that the production of SDF-1 by BMMSCs was significantly reduced in the presence of activated MCs (Figure 3) suggests a possible mechanism for the increased mobilization of $\mathrm{CD}_{3} 4^{+}$progenitor cells from the $\mathrm{BM}$ after allergen challenge, because SDF-1 plays an important role in the homing and retention of progenitor cells to the BM $(11,32)$. The observation that the MCs mediators could induce TSLP production by BM-MSCs only in the presence of TNF could explain how chronic inflammation increases the sensitization of the airways to the allergen $(33,34)$. Notably, MCs can release TNF, especially after IgE-mediated activation (35). In keeping with this, TNF was reported to upregulate PAR-2 expression on endothelial cells (36). Although it is tempting to speculate that serine proteases, including tryptase, which is a natural ligand of PAR-2, could be implicated in the induction of TSLP via PAR-2-dependent mechanism, as it was reported for epithelial cells (37), the exact mechanism of TSLP induction by BM-MSCs upon stimulation with activated MCs still remains to be elucidated.
In conclusion, this study demonstrates that inflammation and IgE-activated MCs stimulate BM-MSCs to release TSLP and other growth factors, which in turn regulate proliferation and lineage commitment of $\mathrm{CD} 34^{+}$progenitor cells and also their production of Th2 cytokines. The in vivo relevance of these in vitro experiments and the obvious question of how MCs-released mediators at the site of allergen exposure reach the BM within minutes remain to be determined. There is an emerging understanding of precisely how this could happen via insoluble particles composed primarily of heparin and cationic proteins, forming extracellular chaperons and protecting these mediators from dilution into interstitial space and degradation (38). Altogether, the present data further underline the important role of MCs in the pathophysiology of allergic diseases by showing that these cells not only display proinflammatory activity at the site of allergen exposure but also induce systemic response involving the BM (Figure 6), as it has been suggested (39).

\section{AUTHOR CONTRIBUTIONS}

All authors have contributed to the collection of the data. Zoulfia Allakhverdi and Guy Delespesse contributed to the conception and design of the work. Zoulfia Allakhverdi, Michael R. Comeau, Rachana Agrawal, Judith A. Woodfolk, Roma Sehmi, Karen J. Howie, Gail M. Gauvreau, and Guy Delespesse contributed to the data analysis and its interpretation. All authors have approved the submission of the manuscript.

\section{ACKNOWLEDGMENTS}

We gratefully acknowledge the group of nurses and obstetricians at St-Luc Hospital (Montreal, QC, Canada) for providing us with umbilical cord blood. This work was supported by a grant from Allergen. Zoulfia Allakhverdi was a recipient of Parker B. Francis fellowship.

\section{REFERENCES}

1. Gibson PG, Manning PJ, O’Byrne PM, Girgis-Gabardo A, Dolovich J, Denburg JA, et al. Allergen-induced asthmatic responses. Relationship between increases in airway responsiveness and increases in circulating eosinophils, basophils, and their progenitors. Am Rev Respir Dis (1991) 143(2):331-5. doi:10.1164/ajrccm/143.2.331

2. Sehmi R, Howie K, Sutherland DR, Schragge W, O’Byrne PM, Denburg JA. Increased levels of CD34+ hemopoietic progenitor cells in atopic subjects. Am J Respir Cell Mol Biol (1996) 15(5):645-55. doi:10.1165/ajrcmb.15.5.8918371

3. Saito H, Matsumoto K, Denburg AE, Crawford L, Ellis R, Inman MD, et al. Pathogenesis of murine experimental allergic rhinitis: a study of local and systemic consequences of IL-5 deficiency. J Immunol (2002) 168(6):3017-23.

4. Allakhverdi Z, Comeau MR, Smith DE, Toy D, Endam LM, Desrosiers M, et al. CD34+ hemopoietic progenitor cells are potent effectors of allergic inflammation. JAllergy Clin Immunol (2009) 123(2):472-8. doi:10.1016/j.jaci.2008.10.022

5. Bianco P, Cao X, Frenette PS, Mao JJ, Robey PG, Simmons PJ, et al. The meaning, the sense and the significance: translating the science of mesenchymal stem cells into medicine. Nat Med (2013) 19(1):35-42. doi:10.1038/nm.3028

6. Méndez-Ferrer S, Michurina TV, Ferraro F, Mazloom AR, MacArthur BD, Lira SA, et al. Mesenchymal and haematopoietic stem cells form a unique bone marrow niche. Nature (2010) 466(7308):829-34. doi:10.1038/nature09262

7. Sacchetti B, Funari A, Michienzi S, Di Cesare S, Piersanti S, Saggio I, et al. Self-renewing osteoprogenitors in bone marrow sinusoids can organize a hematopoietic microenvironment. Cell (2007) 131(2):324-36. doi:10.1016/j. cell.2007.08.025

8. Dazzi F, Lopes L, Weng L. Mesenchymal stromal cells: a key player in innate tolerance'? Immunology (2012) 137(3):206-13. doi:10.1111/j.1365-2567.2012. 03621.x 
9. Allakhverdi Z, Comeau MR, Jessup HK, Yoon BR, Brewer A, Chartier S, et al. Thymic stromal lymphopoietin is released by human epithelial cells in response to microbes, trauma, or inflammation and potently activates mast cells. J Exp Med (2007) 204(2):253-8. doi:10.1084/jem.20062211

10. Kirshenbaum AS, Metcalfe DD. Growth of human mast cells from bone marrow and peripheral blood-derived CD34+ pluripotent progenitor cells. Methods Mol Biol (2006) 315:105-12.

11. Dorman SC, Babirad I, Post J, Watson RM, Foley R, Jones GL, et al. Progenitor egress from the bone marrow after allergen challenge: role of stromal cellderived factor 1alpha and eotaxin. J Allergy Clin Immunol (2005) 115(3):501-7. doi:10.1016/j.jaci.2004.11.017

12. Zeibecoglou K, Ying S, Yamada T, North J, Burman J, Bungre J, et al. Increased mature and immature CCR3 messenger RNA+ eosinophils in bone marrow from patients with atopic asthma compared with atopic and nonatopic control subjects. J Allergy Clin Immunol (1999) 103(1 Pt 1):99-106. doi:10.1016/S00916749(99)70532-4

13. Dorman SC, Efthimiadis A, Babirad I, Watson RM, Denburg JA, Hargreave FE, et al. Sputum CD34+IL-5Ralpha+ cells increase after allergen: evidence for in situ eosinophilopoiesis. Am J Respir Crit Care Med (2004) 169(5):573-7. doi:10.1164/rccm.200307-1004OC

14. Iwasaki H, Akashi K. Myeloid lineage commitment from the hematopoietic stem cell. Immunity (2007) 26(6):726-40. doi:10.1016/j.immuni.2007.06.004

15. Schneider E, Thieblemont N, De Moraes ML, Dy M. Basophils: new players in the cytokine network. Eur Cytokine Netw (2010) 21(3):142-53. doi:10.1684/ecn. 2010.0197

16. Kim YK, Uno M, Hamilos DL, Beck L, Bochner B, Schleimer R, et al. Immunolocalization of CD34 in nasal polyposis. Effect of topical corticosteroids. Am J Respir Cell Mol Biol (1999) 20(3):388-97. doi:10.1165/ajrcmb.20.3.3060

17. Walker SA, Riches PG, Wild G, Ward AM, Shaw PJ, Desai S, et al. Total and allergen-specific IgE in relation to allergic response pattern following bone marrow transplantation. Clin Exp Immunol (1986) 66(3):633-9.

18. Agosti JM, Sprenger JD, Lum LG, Witherspoon RP, Fisher LD, Storb R, et al. Transfer of allergen-specific IgE-mediated hypersensitivity with allogeneic bone marrow transplantation. N Engl J Med (1988) 319(25):1623-8. doi:10.1056/ NEJM198812223192502

19. Corris PA, Dark JH. Aetiology of asthma: lessons from lung transplantation. Lancet (1993) 341(8857):1369-71. doi:10.1016/0140-6736(93)90941-9

20. Mendez-Ferrer S, Lucas D, Battista M, Frenette PS. Haematopoietic stem cell release is regulated by circadian oscillations. Nature (2008) 452(7186):442-7. doi:10.1038/nature06685

21. Le Blanc K, Frassoni F, Ball L, Locatelli F, Roelofs H, Lewis I, et al. Mesenchymal stem cells for treatment of steroid-resistant, severe, acute graft-versus-host disease: a phase II study. Lancet (2008) 371(9624):1579-86. doi:10.1016/S01406736(08)60690-X

22. Wang D, Zhang H, Liang J, Li X, Feng X, Wang H, et al. Allogeneic mesenchymal stem cell transplantation in severe and refractory systemic lupus erythematosus: 4 years experience. Cell Transplant (2012). doi:10.3727/096368912X658719

23. Hare JM, Fishman JE, Gerstenblith G, DiFede Velazquez DL, Zambrano JP, Suncion VY, et al. Comparison of allogeneic vs autologous bone marrow-derived mesenchymal stem cells delivered by transendocardial injection in patients with ischemic cardiomyopathy: the POSEIDON randomized trial. JAMA (2012) 308(22):2369-79. doi:10.1001/jama.2012.25321

24. Bai L, Lennon DP, Eaton V, Maier K, Caplan AI, Miller SD, et al. Human bone marrow-derived mesenchymal stem cells induce Th2-polarized immune response and promote endogenous repair in animal models of multiple sclerosis. Glia (2009) 57(11):1192-203. doi:10.1002/glia.20841

25. Wang Q, Sun B, Wang D, Ji Y, Kong Q, Wang G, et al. Murine bone marrow mesenchymal stem cells cause mature dendritic cells to promote T-cell tolerance. Scand J Immunol (2008) 68(6):607-15. doi:10.1111/j.1365-3083.2008.02180.x

26. Aalbers R, de Monchy JG, Kauffman HF, Smith M, Hoekstra Y, Vrugt B, et al Dynamics of eosinophil infiltration in the bronchial mucosa before and after the late asthmatic reaction. Eur Respir J (1993) 6(6):840-7.

27. Gauvreau GM, Watson RM, O'Byrne PM. Kinetics of allergen-induced airway eosinophilic cytokine production and airway inflammation.
Am J Respir Crit Care Med (1999) 160(2):640-7. doi:10.1164/ajrccm.160. 2.9809130

28. Siracusa MC, Saenz SA, Hill DA, Kim BS, Headley MB, Doering TA, et al. TSLP promotes interleukin-3-independent basophil haematopoiesis and type 2 inflammation. Nature (2011) 477(7363):229-33. doi:10.1038/ nature 10329

29. Hogan MB, Piktel D, Landreth KS. IL-5 production by bone marrow stromal cells: implications for eosinophilia associated with asthma. J Allergy Clin Immunol (2000) 106(2):329-36. doi:10.1067/mai.2000.108309

30. Sehmi R, Wood LJ, Watson R, Foley R, Hamid Q, O’Byrne PM, et al. Allergeninduced increases in IL-5 receptor alpha-subunit expression on bone marrowderived CD34+ cells from asthmatic subjects. A novel marker of progenitor cell commitment towards eosinophilic differentiation. J Clin Invest (1997) 100(10):2466-75. doi:10.1172/JCI119789

31. Miyata M, Hatsushika K, Ando T, Shimokawa N, Ohnuma Y, Katoh R, et al. Mast cell regulation of epithelial TSLP expression plays an important role in the development of allergic rhinitis. Eur J Immunol (2008) 38(6):1487-92. doi:10.1002/eji.200737809

32. Kucia M, Jankowski K, Reca R, Wysoczynski M, Bandura L, Allendorf DJ, et al. CXCR4-SDF-1 signalling, locomotion, chemotaxis and adhesion. J Mol Histol (2004) 35(3):233-45. doi:10.1023/B:HIJO.0000032355.66152.b8

33. Holgate ST. The sentinel role of the airway epithelium in asthma pathogenesis. Immunol Rev (2011) 242(1):205-19. doi:10.1111/j.1600-065X.2011.01030.x

34. Sin B, Togias A. Pathophysiology of allergic and nonallergic rhinitis. Proc Am Thorac Soc (2011) 8(1):106-14. doi:10.1513/pats.201008-057RN

35. Gordon JR, Galli SJ. Release of both preformed and newly synthesized tumor necrosis factor alpha (TNF-alpha)/cachectin by mouse mast cells stimulated via the Fc epsilon RI. A mechanism for the sustained action of mast cellderived TNF-alpha during IgE-dependent biological responses. J Exp Med (1991) 174(1):103-7.

36. Hamilton JR, Frauman AG, Cocks TM. Increased expression of proteaseactivated receptor-2 (PAR2) and PAR4 in human coronary artery by inflammatory stimuli unveils endothelium-dependent relaxations to PAR2 and PAR4 agonists. Circ Res (2001) 89(1):92-8. doi:10.1161/hh1301.092661

37. Kouzaki H, O'Grady SM, Lawrence CB, Kita H. Proteases induce production of thymic stromal lymphopoietin by airway epithelial cells through proteaseactivated receptor-2. J Immunol (2009) 183(2):1427-34. doi:10.4049/jimmunol. 0900904

38. Kunder CA, St John AL, Li G, Leong KW, Berwin B, Staats HF, et al. Mast cellderived particles deliver peripheral signals to remote lymph nodes. J Exp Med (2009) 206(11):2455-67. doi:10.1084/jem.20090805

39. Togias A. Systemic effects of local allergic disease. J Allergy Clin Immunol (2004) 113(1 Suppl):S8-14. doi:10.1016/j.jaci.2003.09.051

Conflict of Interest Statement: The authors declare that the research was conducted in the absence of any commercial or financial relationships that could be construed as a potential conflict of interest. Michael R. Comeau is an employee and shareholder of Amgen Inc.

Received: 28 October 2013; accepted: 03 December 2013; published online: 17 December 2013.

Citation: Allakhverdi Z, Comeau MR, Armant M, Agrawal R, Woodfolk JA, Sehmi R, Howie KJ, Gauvreau GM and Delespesse G (2013) Mast cell-activated bone marrow mesenchymal stromal cells regulate proliferation and lineage commitment of $\mathrm{CD} 34^{+}$ progenitor cells. Front. Immunol. 4:461. doi: 10.3389/fimmu.2013.00461

This article was submitted to Inflammation, a section of the journal Frontiers in Immunology.

Copyright (c) 2013 Allakhverdi, Comeau, Armant, Agrawal, Woodfolk, Sehmi, Howie, Gauvreau and Delespesse. This is an open-access article distributed under the terms of the Creative Commons Attribution License (CC BY). The use, distribution or reproduction in other forums is permitted, provided the original author(s) or licensor are credited and that the original publication in this journal is cited, in accordance with accepted academic practice. No use, distribution or reproduction is permitted which does not comply with these terms. 